\title{
Teaching Video NeuroImages: Opsoclonus in anti-DPPX encephalitis
}

Jonathan A. Micieli, MD, Nancy J. Newman, MD, Carlos S. Kase, MD, and Valérie Biousse, MD

Neurology ${ }^{\circledR}$ 2019;92:e2298. doi:10.1212/WNL.0000000000007463

A 49-year-old man presented with a 15-month history of binocular diplopia and oscillopsia and a 6-month history of headaches, memory loss, anorexia, myalgias, and unintentional 105-pound weight loss without diarrhea. Neuro-ophthalmic assessment revealed episodic bursts of opsoclonus, intermittent jerk nystagmus, saccadic pursuit, and slowed and dysmetric saccades, and he was unable to maintain fixation (video 1). Anti-DPPX antibodies were positive in the CSF. He was treated with IV methylprednisolone, plasmapheresis, and rituximab, and his ocular symptoms resolved several months after treatment. Opsoclonus is an ocular manifestation of anti-DPPX encephalitis, which may also cause nystagmus, skew deviation, and saccadic pursuit due to DPPX expression in the cerebellum. ${ }^{1,2}$

\section{Author contributions}

J.A. Micieli: study conception and design, manuscript preparation. N.J. Newman: study conception and design, final approval of manuscript. C.S. Kase: study conception and design, final approval of manuscript. V. Biousse: study conception and design, final approval of manuscript.

\section{Study funding}

This study was supported in part by an unrestricted departmental grant (Department of Ophthalmology) from Research to Prevent Blindness, Inc., New York, and by NIH/NEI core grant P30-EY006360 (Department of Ophthalmology).

\section{Disclosure}

The authors report no disclosures relevant to the manuscript. Go to Neurology.org/ $\mathrm{N}$ for full disclosures.

\section{References}

1. Tobin WO, Lennon VA, Komorowski L, et al. DPPX potassium channel antibody: frequency, clinical accompaniments, and outcomes in 20 patients. Neurology 2014;83:1797-1803.

2. Balint B, Jarius S, Nagel S, et al. Progressive encephalomyelitis with rigidity and myoclonus: a new variant with DPPX antibodies. Neurology 2014;82:1521-1528.

\author{
Correspondence \\ Dr. Micieli \\ jmicieli@ \\ kensingtonhealth.org
}

MORE ONLINE

- Video

$\rightarrow$ Teaching slides

links.lww.com/WNL/

A875 


\section{Neurology}

\section{Teaching Video NeuroImages: Opsoclonus in anti-DPPX encephalitis \\ Jonathan A. Micieli, Nancy J. Newman, Carlos S. Kase, et al. \\ Neurology 2019;92; 2298 \\ DOI 10.1212/WNL.0000000000007463}

This information is current as of May 6, 2019

\section{Updated Information \& Services}

References

Subspecialty Collections

Permissions \& Licensing

Reprints including high resolution figures, can be found at: http://n.neurology.org/content/92/19/e2298.full

This article cites 2 articles, 2 of which you can access for free at: http://n.neurology.org/content/92/19/e2298.full\#ref-list-1

This article, along with others on similar topics, appears in the following collection(s):

Autoimmune diseases

http://n.neurology.org/cgi/collection/autoimmune_diseases

Ocular motility

http://n.neurology.org/cgi/collection/ocular_motility

Oscillopsia

http://n.neurology.org/cgi/collection/oscillopsia

Information about reproducing this article in parts (figures,tables) or in its entirety can be found online at:

http://www.neurology.org/about/about_the_journal\#permissions

Information about ordering reprints can be found online:

http://n.neurology.org/subscribers/advertise

Neurology ${ }^{\circledR}$ is the official journal of the American Academy of Neurology. Published continuously since 1951, it is now a weekly with 48 issues per year. Copyright (O 2019 American Academy of Neurology. All rights reserved. Print ISSN: 0028-3878. Online ISSN: 1526-632X.

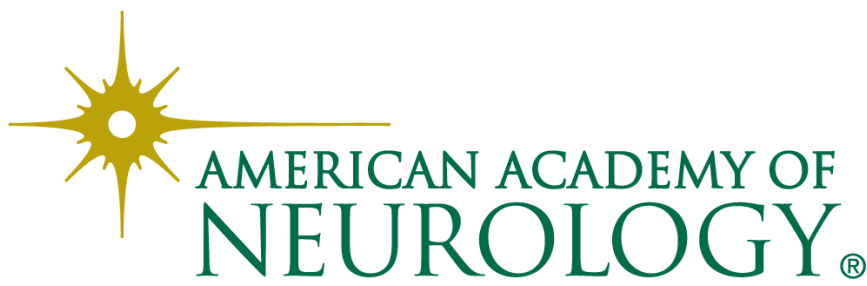

